\title{
Mesquite (Prosopis juliflora) extract as a phytogenic additive for sheep finished on pasture in the semiarid region
}

\author{
Juliana P. Férrer ${ }^{1}$, Márcio V. da Cunha², Mércia V.F. dos Santos ${ }^{2}$, Thaysa R. Torres ${ }^{3}$, José R.C. da Silva ${ }^{1}$, \\ Robson M.L. Véras ${ }^{1}$, Daniel C. da Silva ${ }^{4}$, Alisson H. da Silva ${ }^{3}$, Luana M.D. Queiroz ${ }^{3}$, Moisés T. Férrer ${ }^{1}$, \\ Elias L.S. Neto ${ }^{3}$, David M. Jaramillo ${ }^{5}$, and Evaristo J.O. de Souza ${ }^{3^{*}}$ \\ ${ }^{1}$ Universidade Federal Rural de Pernambuco, Unidade Acadêmica de Garanhuns, Avenida Bom Pastor s/n, 55296120 Garanhuns, \\ Pernambuco, Brasil. \\ ${ }^{2}$ Universidade Federal Rural de Pernambuco, Departamento de Zootecnia, Rua Dom Manoel de Medeiros s/n, 52171-900, Recife, \\ Pernambuco, Brasil. \\ ${ }^{3}$ Universidade Federal Rural de Pernambuco, Unidade Acadêmica de Serra Talhada, Avenida Gregório Ferraz Nogueira s/n, 56909-535, \\ Serra Talhada, Pernambuco, Brasil.*Corresponding author (evaristojorge@gmail.com). \\ ${ }^{4}$ Instituto Federal de Educação, Ciência e Tecnologia da Paraíba, Rua Presidente Tancredo Neves s/n, 5881-4000, Sousa, Paraíba Brasil. \\ ${ }^{5}$ University of Florida, Institute of Food and Agricultural Sciences (IFAS), North Florida Research and Education Center Marianna, \\ 3925 FL-71, 32446 Greenwood, Florida, USA.
}

Received: 21 August 2020; Accepted: 14 October 2020; doi:10.4067/S0718-58392021000100014

\begin{abstract}
Phytogenic additives are organic molecules that also improve ruminal fermentation, turning the supplemented individuals into more productive animals, without damage the population welfare. The objective of this study was to evaluate the effects of mesquite (Prosopis juliflora [Sw.] DC.) extract as phytogenic additive for sheep finished on pasture in the Brazilian Northeast semiarid region. Twenty-four intact lambs (Santa Ines $\times$ Dorper $F_{1}$ crossbred) were used, with an initial body weight of $23.00 \pm 1.83 \mathrm{~kg}$. The experiment was carried out in a complete randomized design with four treatments and six replicates. Treatments consisted of four diets: Pasture and no supplementation; grazing pasture and phytogenic additive; pasture, supplementation with Tifton 85 hay, and concentrate; and pasture, phytogenic additive, and supplementation with Tifton 85 hay and concentrate. Prior to supplementation, animals received the phytogenic additive according to treatment. There were nonsignificant differences for nutrient intake and behavior patterns $(\mathrm{P}>0.05)$. However, additive intake derived from mesquite provided an increase $(\mathrm{P}<0.05)$ in digestibility $(14.40 \%$ total digestible nutrients), $\mathrm{N}$ balance $(27.12 \%$ retained $\mathrm{N}$ :ingested $\mathrm{N}$ ) and performance ( $8.82 \%$ final body weight, $21.81 \%$ total weight gain, and $30.81 \%$ average daily gain) compared to animals consuming only pasture in rainy period. Thus, the use of mesquite extract as phytogenic additive is recommended for sheep finished on pasture in the Brazilian semiarid region.
\end{abstract}

Key words: Bioactive compounds, caatinga, digestibility of nutrients, intake, tannins.

\section{INTRODUCTION}

Most of the sheep herds in the Brazilian Northeast semiarid regions are reared using extensive regimes and with native vegetation (Caatinga) as the main diet source. Marques et al. (2020) reported that Caatinga is a seasonally dry tropical forest with vegetation composed primarily of trees and shrubs morphologically adapted to tolerate water deficit stress. Forage and grazing management practices have not been adequately developed in this region, which has resulted in poor nutrition and livestock performance (Silva et al., 2010). 
In recent years there has been a certain increase in demand for sheep meat, reflecting changes in the eating habits of consumers. In parallel, there has also been an increase in quality requirements related to several factors of animals and also a better nutritional management of the livestock, which could raise production costs. One potential way to improve nutritional quality, increase production levels and reduce production costs is the use and implementation of ruminal fermentation modifiers and additives (Possamai et al., 2011).

Ionophores are potential feed additives that affect ruminal fermentation through modifying the microbial population, inhibiting gram-positive bacteria and selecting gram-negative bacteria. However, there are problems related to residues in tissues arising from animals whose production included the use of such antibiotics (Catalan et al., 2012; Pavarini et al., 2012). Silva et al. (2016) and Alves Júnior et al. (2017) reported that use secondary compounds as phytogenic additives in ruminant nutrition is a promising alternative, as it improves the efficiency of nutrient use by ruminants.

Plants produce several organic compounds and most do not seem to participate directly in plant growth and development. Their important role performing functions related to the survival and the perpetuation of species is known. However, they exist only in specific organisms (Agrawal and Weber, 2015; Abdelmohsen et al., 2015). Abdelmohsen et al. (2015) consider secondary metabolism as the chemistry of natural products. One of the representatives of such products, of interest for production, is tannin, one of the secondary metabolites of plants. This compound is not involved in processes considered essential for plants (Cabral Filho et al., 2013). Tannins improve digestibility of nutrients, optimizing production of propionic acid, microbial protein synthesis and reduce the number of ciliate protozoa (Castro-Montoya et al., 2011; Alves Júnior et al., 2017).

When tannin is used at adequate concentrations and there is a decrease of gram-positive bacteria, an increase of gramnegative bacteria is common, which, in turn, increases their multiplication rate. Tannins may act creating a lysis in the cell of protozoa, culminating with their cellular death and therefore increasing the number of bacteria that will act on the food ingested. This is beneficial because it makes rumen degradation of foods more efficient, consequently improving digestibility (Bodas et al., 2012; Durmic and Blache, 2012; Flachowsky and Lebzien, 2012; Oskoueian et al., 2013).

Sheep breeding may benefit from secondary compounds used as phytogenic additives, which have ionophore-like mechanisms of action without producing final product residues (Alves Júnior et al., 2017), especially when it comes to the semiarid region, where plants with secondary metabolites are abundant (Chaves et al., 2013). An example is mesquite (Prosopis juliflora [Sw.] DC.), a valuable option to be explored as a phytogenic additive (Silva et al., 2016; Alves Júnior et al., 2017).

Prosopis juliflora is a tree legume able to survive in environments with little water and acidic soils. It also produces fruits (pods) during periods with food shortages (Andrade-Montemayor et al., 2011; Ali et al., 2012). Moraes et al. (2016) discuss the nutritive value of $P$. juliflora pods, and Silva et al. (2016) found condensed tannins in mesquite pod samples.

Based on the considerations above, this study aimed to evaluate the effects of mesquite extract as phytogenic additive about performance, nutrient intake, nutrient digestibility, $\mathrm{N}$ use efficiency and microbial protein synthesis in sheep finished on pasture in the Brazilian semiarid region.

\section{MATERIALS AND METHODS}

This study was carried out in strict accordance with the recommendations of the Brazilian guide of the National Council for the Control of Animal Experimentation (CONCEA). The protocol was approved by the Committee on the Ethics of Animal Experiments of the Federal Rural University of Pernambuco, Pernambuco State, Brazil (approval nr 005/2014).

\section{Site, facilities and period}

The experiment was conducted in a commercial farm utilizing an area of 37.9 ha located in the city of Serra Talhada, semiarid region, inside the microregion of Sertão do Pajeú, a Caatinga (seasonally dry tropical forest) area with herbaceous strata, shrub and tree species: Froelichia humboldtiana, Myracrodruon urundeuva, Schinopsis brasiliensis, Aspidosperma pyrifolium, Calotropis procera, Bromelia laciniosa, Neoglaziovia variegata, Bromelia balansae, Pilosocereus gounellei, Opuntia inamoena, Melocactus bahiensis, Cereus jamacaru, Ipomoea asarifolia, Croton heliotropiifolius, Cnidoscolus urens, Cnidoscolus phyllacanthus, Jatropha mollissima, Croton blanchetianus, Manihot glaziovii, Poincianella pyramidalis, Bauhinia cheilantha, Mimosa tenuiflora, Prosopis juliflora, Caesalpinia 
ferrea, Hyptis fruticosa, Boerhavia diffusa, Cenchrus ciliaris, Melinis repens, Urochloa mosambicensis, Brachiaria plantaginea, Portulaca oleracea, Ziziphus joazeiro, Staelia virgata, Borreria verticillata, Sideroxylon obtusifolium, Waltheria rotundifolia, and Melochia tomentosa.

The grazing season was from February to June 2015, and the experimental period comprised $84 \mathrm{~d}$, sub-divided into three periods of $28 \mathrm{~d}$. Period 1 (rainy) was from 25 March to 21 April, period 2 (transition) was from 22 April to 19 May, and period 3 (drought) from 20 May to 16 June. The forage mass within the experimental area varied according to the experimental period. An average of 220 points was distributed into 11 transects in the pasture (Table 1). The average rainfall was $93 \mathrm{~mm}$ in period 1, characterized as rainy; $52.4 \mathrm{~mm}$ in period 2, characterized as a transition period; and 5.8 $\mathrm{mm}$ in period 3 , a drought period (IPA, 2015).

\section{Treatments and animals}

The treatments consisted of four diets: No supplementation in which animals consumed only Caatinga vegetation (grazing pasture); Caatinga vegetation and the phytogenic additive (Caatinga + Additive); Caatinga vegetation and supplementation with Tifton 85 hay and concentrate (Caatinga + Supplement); Caatinga vegetation, the phytogenic additive and supplementation with Tifton 85 hay and concentrate (Caatinga + Additive + Supplement). The supplementation was composed of Tifton 85 hay (Cynodon spp., a hybrid strain from the cross of Cynodon nlemfuensis with C. dactylon registered as PI 290884) and concentrate (Table 2) with $192.5 \mathrm{~g}$ crude protein $\mathrm{kg}^{-1} \mathrm{DM}$. It was offered on the basis of $1 \%$ of body weight (BW), providing an average daily gain of $100 \mathrm{~g} \mathrm{~d}^{-1}$, according to the NRC (2007). The supplementation was adjusted to BW every $28 \mathrm{~d}$ when lambs were weighed.

For the preparation of additive, mesquite (Prosopis juliflora [Sw.] DC) pods were collected directly from the Caatinga. Broken pods and those contaminated by pests and or diseases were discarded. Healthy pods were frozen at $-20{ }^{\circ} \mathrm{C}$. The mesquite pods were processed by crushing with pliers. Then, $60 \mathrm{~g}$ of material were weighed and placed in a sealed plastic container. In a separate container, water was heated to $100{ }^{\circ} \mathrm{C}$. Finally, $100 \mathrm{~mL}$ boiled water were added to the crushed mesquite pod material, mixed by hand and held for $30 \mathrm{~min}$ in closed container. Following the $30 \mathrm{~min}$ extraction period, the additive (liquid of mesquite resulting from extraction) was removed and administered orally with a syringe to animals in the additive treatment. Additive was administered to treatment animals at a rate of $6 \mathrm{~mL} \mathrm{~d}^{-1}$ at a concentration of $600 \mathrm{mg} \mathrm{mL}^{-1}$. The additive was prepared and administered fresh each day of the feeding period.

Twenty-four intact lambs (Santa Ines $\times$ Dorper $F_{1}$ crossbred) were used, with initial body weight of $23.00 \pm 1.83 \mathrm{~kg}$ and averaged 6 mo of age. Lambs were weighed prior to the beginning of the experiment, after a $16 \mathrm{~h}$ fasting period. The animals were treated for internal and external parasites by administration of doramectin (dose $1 \mathrm{~mL}^{2} \mathrm{~kg}^{-1} \mathrm{BW}$; Dectomax, Zoetis, São Paulo, Brazil) prior the beginning of the experiment.

The animals had access to pasture with Caatinga vegetation from 07:00 $\mathrm{h}$ and were collected to the sheepfold at 17:00 $\mathrm{h}$, where two groups were kept in individual pens and were provided with feeders and water fountains in order to receive feed supplement. The two other groups, which did not receive supplement, were kept in collective pens.

Animals receiving the phytogenic additive were given the additive orally after grazing. For the group that received supplementation, animals were given the additive and then supplemented. The animals submitted to treatments that did not receive the additive, after arriving from grazing, had supplementation offered. Animals not supplemented and not receiving the additive were only placed in their pens for rest and subsequent release the next day, and had mineral supplementation (Suprafós 70, Supranor, Recife, Pernambuco, Brazil). For all treatments, there was water supply ad libitum.

Table 1. Uncovered soil, litter, herbaceous stratum height and forage mass in a Caatinga area grazed by sheep.

\begin{tabular}{|c|c|c|c|c|c|c|}
\hline \multirow[b]{2}{*}{ Variables } & \multicolumn{2}{|c|}{ Rainy period } & \multicolumn{2}{|c|}{ Transition period } & \multicolumn{2}{|c|}{ Drought period } \\
\hline & Beginning & End & Beginning & End & Beginning & End \\
\hline Uncovered soil, \% & $22.91 \pm 19$ & $32.58 \pm 17$ & $32.58 \pm 17$ & $45.54 \pm 22$ & $45.54 \pm 22$ & $49.67 \pm 23$ \\
\hline Litter, \% & $8.51 \pm 16$ & $17.00 \pm 12$ & $17.00 \pm 12$ & $22.78 \pm 17$ & $22.78 \pm 17$ & $18.45 \pm 18$ \\
\hline Plant height, $\mathrm{cm}$ & $47.13 \pm 42$ & $48.54 \pm 44$ & $48.54 \pm 44$ & $53.24 \pm 47$ & $53.24 \pm 47$ & $44.45 \pm 39$ \\
\hline Forage mass, $\mathrm{kg} \mathrm{DM} \mathrm{ha-1}$ & $1123 \pm 355$ & $1015 \pm 479$ & $1015 \pm 479$ & $707 \pm 316$ & $707 \pm 316$ & $335 \pm 114$ \\
\hline
\end{tabular}

Each value corresponds to an average of 220 points distributed into 11 transects in pasture \pm standard deviation. 
Table 2. Chemical composition of the supplement and the phytogenic additive.

\begin{tabular}{|c|c|c|c|}
\hline \multirow[b]{2}{*}{ Nutrients } & \multicolumn{3}{|c|}{ Ingredients } \\
\hline & Tifton 85 hay & Soybean meal & Corn meal \\
\hline Dry matter, $\mathrm{g} \mathrm{kg}^{-1} \mathrm{NM}$ & 920.90 & 915.50 & 907.70 \\
\hline Organic matter, $\mathrm{g} \mathrm{kg}^{-1} \mathrm{DM}$ & 939.33 & 933.07 & 988.26 \\
\hline Crude protein, $\mathrm{g} \mathrm{kg}^{-1} \mathrm{DM}$ & 45.90 & 512.00 & 94.90 \\
\hline Ether extract, $\mathrm{g} \mathrm{kg}^{-1} \mathrm{DM}$ & 21.00 & 21.70 & 51.60 \\
\hline Total carbohydrates, $\mathrm{g} \mathrm{kg}^{-1} \mathrm{DM}$ & 872.43 & 399.37 & 841.76 \\
\hline Neutral detergent fiber, $\mathrm{g} \mathrm{kg}^{-1} \mathrm{DM}$ & 757.20 & 120.10 & 143.70 \\
\hline Non-fibrous carbohydrates, $\mathrm{g} \mathrm{kg}^{-1} \mathrm{DM}$ & 115.23 & 279.27 & 698.06 \\
\hline \multicolumn{4}{|c|}{ Supplement } \\
\hline Ingredients & \multicolumn{3}{|c|}{ Proportions of ingredients ${ }^{1}$} \\
\hline Tifton 85 hay, $\mathrm{g} \mathrm{kg}^{-1} \mathrm{DM}$ & \multicolumn{3}{|c|}{300.00} \\
\hline Soybean meal, $\mathrm{g} \mathrm{kg}^{-1} \mathrm{DM}$ & \multicolumn{3}{|c|}{280.00} \\
\hline Corn meal, $\mathrm{g} \mathrm{kg}^{-1} \mathrm{DM}$ & \multicolumn{3}{|c|}{400.00} \\
\hline Mineral salt ${ }^{1}, \mathrm{~g} \mathrm{~kg}^{-1} \mathrm{DM}$ & \multicolumn{3}{|c|}{20.00} \\
\hline Nutrients & \multicolumn{3}{|c|}{ Nutritional composition } \\
\hline Dry matter, $\mathrm{g} \mathrm{kg}^{-1} \mathrm{NM}$ & \multicolumn{3}{|c|}{911.40} \\
\hline Organic matter, $\mathrm{g} \mathrm{kg}^{-1} \mathrm{DM}$ & \multicolumn{3}{|c|}{940.10} \\
\hline Crude protein, $\mathrm{g} \mathrm{kg}^{-1} \mathrm{DM}$ & \multicolumn{3}{|c|}{192.50} \\
\hline Ether extract, $\mathrm{g} \mathrm{kg}^{-1} \mathrm{DM}$ & \multicolumn{3}{|c|}{120.50} \\
\hline Total carbohydrates, $\mathrm{g} \mathrm{kg}^{-1} \mathrm{DM}$ & \multicolumn{3}{|c|}{626.90} \\
\hline Neutral detergent fiber, $\mathrm{g} \mathrm{kg}^{-1} \mathrm{DM}$ & \multicolumn{3}{|c|}{390.30} \\
\hline Non-fibrous carbohydrates, $\mathrm{g} \mathrm{kg}^{-1} \mathrm{DM}$ & \multicolumn{3}{|c|}{236.50} \\
\hline \multicolumn{4}{|c|}{ Phytogenic additive } \\
\hline Condensed tannins & \multicolumn{3}{|c|}{ Chemical composition } \\
\hline Soluble condensed tannins, $\mathrm{g} \mathrm{kg}^{-1} \mathrm{DM}$ & \multicolumn{3}{|c|}{37.16} \\
\hline Protein-bound condensed tannins, $\mathrm{g} \mathrm{kg}^{-1} \mathrm{DM}$ & \multicolumn{3}{|c|}{209.30} \\
\hline Fiber-bound condensed tannins, $\mathrm{g} \mathrm{kg}^{-1} \mathrm{DM}$ & \multicolumn{3}{|c|}{7.68} \\
\hline Total condensed tannins, $\mathrm{g} \mathrm{kg}^{-1} \mathrm{DM}$ & \multicolumn{3}{|c|}{254.14} \\
\hline
\end{tabular}

NM: Natural matter.

${ }^{1}$ Composition (nutrient kg-1 product): $140 \mathrm{~g} \mathrm{Ca} \mathrm{kg}^{-1} ; 70 \mathrm{~g} \mathrm{P} \mathrm{kg}^{-1} ; 1320 \mathrm{mg} \mathrm{Mg} \mathrm{kg}{ }^{-1} ; 2200 \mathrm{mg} \mathrm{Fe} \mathrm{kg}{ }^{-1} ; 140$ mg Co kg ;

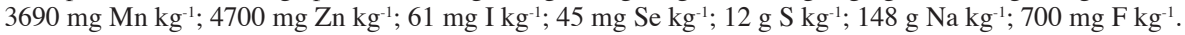

Weighting occurred every $28 \mathrm{~d}$, after animals underwent a $16 \mathrm{~h}$ fasting period. Supplement quantities offered and leftovers were daily recorded. During the collection period, collected samples were weighed, identified and frozen at $-20{ }^{\circ} \mathrm{C}$ for further analysis.

\section{Pasture samples}

In order to obtain pasture samples (rumen contents; extrusa), to estimate composition during each collection period, four rumen-fistulated sheep were used. Their feeding diet during the experimental period consisted of native pasture, mineral salt and water ad libitum. Pasture samples were collected in four periods with 21-d intervals during four consecutive days in alternating shifts (morning and afternoon). At the time of collection, all rumen contents were removed and stored in individual buckets, and the animals were subsequently released to the experimental area for $1 \mathrm{~h}$. Following this period, the fistulated animals were returned to the feeding facilities, rumen contents were harvested, and samples per animal and per period were collected, identified and frozen at $-20^{\circ} \mathrm{C}$ to be analyzed at a later date (Table 3). The previously removed material was returned to the rumen (Santos et al., 2008).

\section{Intake and digestibility of nutrients}

At the end of each $28 \mathrm{~d}$ period, during the last $5 \mathrm{~d}$ (from $24^{\text {th }}$ to $28^{\text {th }}$ days of the experimental period), fecal samples, pasture (extrusa), supplement supplied (concentrate and hay) and leftovers (when they existed) were collected daily. The feces were collected before animals went to the pasture, twice a day (in the morning and the afternoon) directly from the rectal ampulla. The collected samples were duly identified and frozen. Initially, samples were thawed and pre-dried in a forced-air ventilation oven at $55 \pm 5^{\circ} \mathrm{C}$ for $72 \mathrm{~h}$, and ground in a type 2 sieve (to determine DM production) with $1 \mathrm{~mm}$ in diameter (for chemical analysis) using a Willey mill for the determination of chemical composition. 
Table 3. Chemical and bromatological composition of plants consumed by the animals.

\begin{tabular}{|c|c|c|}
\hline Nutrients & Nutritional composition & SFM \\
\hline \multicolumn{3}{|c|}{ Rainy period } \\
\hline Dry matter, $\mathrm{g} \mathrm{kg}^{-1} \mathrm{NM}$ & 204.34 & 0.89 \\
\hline Organic matter, $\mathrm{g} \mathrm{kg}^{-1} \mathrm{DM}$ & 875.61 & 0.25 \\
\hline Crude protein, $\mathrm{g} \mathrm{kg}^{-1} \mathrm{DM}$ & 165.13 & 1.56 \\
\hline Ether extract, $\mathrm{g} \mathrm{kg}^{-1} \mathrm{DM}$ & 80.44 & 0.10 \\
\hline Total carbohydrates, $\mathrm{g} \mathrm{kg}^{-1} \mathrm{DM}$ & 630.10 & 1.21 \\
\hline Neutral detergent fiber, $\mathrm{g} \mathrm{kg}^{-1} \mathrm{DM}$ & 575.54 & 1.31 \\
\hline Non-fibrous carbohydrates, $\mathrm{g} \mathrm{kg}^{-1} \mathrm{DM}$ & 54.63 & 0.74 \\
\hline \multicolumn{3}{|c|}{ Transition period } \\
\hline Dry matter, $\mathrm{g} \mathrm{kg}^{-1} \mathrm{NM}$ & 187.10 & 1.00 \\
\hline Organic matter, $\mathrm{g} \mathrm{kg}^{-1} \mathrm{DM}$ & 842.94 & 0.84 \\
\hline Crude protein, $\mathrm{g} \mathrm{kg}^{-1} \mathrm{DM}$ & 141.52 & 1.49 \\
\hline Ether extract, $\mathrm{g} \mathrm{kg}^{-1} \mathrm{DM}$ & 98.33 & 0.46 \\
\hline Total carbohydrates, $\mathrm{g} \mathrm{kg}^{-1} \mathrm{DM}$ & 603.10 & 1.89 \\
\hline Neutral detergent fiber, $\mathrm{g} \mathrm{kg}^{-1} \mathrm{DM}$ & 575.11 & 1.72 \\
\hline Non-fibrous carbohydrates, $\mathrm{g} \mathrm{kg}^{-1} \mathrm{DM}$ & 28.03 & 0.39 \\
\hline \multicolumn{3}{|c|}{ Drought period } \\
\hline Dry matter, $\mathrm{g} \mathrm{kg}^{-1} \mathrm{NM}$ & 223.22 & 0.28 \\
\hline Organic matter, $\mathrm{g} \mathrm{kg}^{-1} \mathrm{DM}$ & 913.13 & 0.45 \\
\hline Crude protein, $\mathrm{g} \mathrm{kg}^{-1} \mathrm{DM}$ & 121.52 & 0.65 \\
\hline Ether extract, $\mathrm{g} \mathrm{kg}^{-1} \mathrm{DM}$ & 118.80 & 0.36 \\
\hline Total carbohydrates, $\mathrm{g} \mathrm{kg}^{-1} \mathrm{DM}$ & 672.82 & 1.02 \\
\hline Neutral detergent fiber, $\mathrm{g} \mathrm{kg}^{-1} \mathrm{DM}$ & 658.70 & 1.03 \\
\hline Non-fibrous carbohydrates, $\mathrm{g} \mathrm{kg}^{-1} \mathrm{DM}$ & 14.17 & 0.04 \\
\hline
\end{tabular}

NM: Natural matter.

To estimate intake and digestibility, fecal DM production (FDMP) was estimated using a digestibility and intake marker (modified and enriched hydroxyphenylpropane; LIPE, p2s2, Florestal, Minas Gerais, Brazil), as an external indicator. Daily doses of $250 \mathrm{mg}$ LIPE animal ${ }^{-1}$ were given orally, starting $2 \mathrm{~d}$ before up to the $5^{\text {th }}$ day of the collection period (from the $22^{\text {nd }}$ to the $28^{\text {th }}$ day of the experimental period), totaling $7 \mathrm{~d}$ of supply. The feces were collected from the third day after the supply of the indicator, according to methodology described by Saliba et al. (2014).

To estimate intake during grazing, LIPE was use in association with a indigestible DM (iDM) used as an internal indicator, obtained after incubation for $288 \mathrm{~h}$ in the rumen-fistulated cattle (thus, all samples were incubated together), adopting for procedures of ruminal incubation: $1 \mathrm{~g}$ samples of extrusa, feces and supplement, ground down to $2 \mathrm{~mm}$ and packed in $4 \times 5 \mathrm{~cm}$ bags of non-woven textile (NWT with a grammage of $100 \mu$ ), following the recommendations of Casali et al. (2008).

\section{Laboratory analyses}

Laboratory analyses were conducted at the Animal Nutrition Laboratory, Universidade Federal Rural de Pernambuco (UFRPE), Garanhuns. Fecal, pasture (extrusa), supplement supplied (concentrate and hay) and leftovers (when they existed) samples were pre-dried in a forced ventilation oven at $55 \pm 5{ }^{\circ} \mathrm{C}$ for $72 \mathrm{~h}$, and ground in a Willey cutting mill with $1 \mathrm{~mm}$ diameter sieves in order to analyze DM (method 967.03), mineral matter (MM) (method 942.05), organic matter (OM) and crude protein (CP) (method 988.05) contents following the recommendations of the Association of Official Analytical Chemists (AOAC, 1990). Neutral detergent fiber (NDF) was analyzed according to Van Soest et al. (1991) using alpha-amylase, as recommended by AOAC (1990). Ether extract (method 920.29) was determined using a Soxhlet type extractions (ANKOM ${ }^{\mathrm{XT}-15}$ extractor, ANKOM Technology, Macedon, New York, USA). The extraction was conducted at a high temperature $\left(90^{\circ} \mathrm{C}\right)$ in a closed system for $60 \mathrm{~min}$ using hexane as organic solvent (AOAC, 1990). For the estimation of total carbohydrates, non-fiber carbohydrates (NFC) and total digestible nutrients (TDN), the equations of Sniffen et al. (1992), Weiss (1999), and Hall (2000) were used. 
Condensed tannins were determined according to Terrill et al. (1992), with purification of the extract and quantification of total condensed tannins (free condensed tannins, protein-bound condensed tannins, and fiber-bound condensed tannins) (Table 2). Daily samples of mesquite pods were collected (when the additive was prepared). Samples were grouped into each period of $28 \mathrm{~d}$, and composited.

\section{Nitrogen use efficiency and microbial protein synthesis}

For $\mathrm{N}$ use efficiency and microbial protein synthesis, we determined the excreted urine volume collected on the last day of each period. Urine samples were obtained by spot collection (spontaneous urination) for approximately $4 \mathrm{~h}$ after animals were released in the pasture (afternoon period). After urination, a $10 \mathrm{~mL}$ aliquot of urine was rapidly diluted into $40 \mathrm{~mL}$ $0.036 \mathrm{~N}$ sulfuric acid $\left(\mathrm{H}_{2} \mathrm{SO}_{4}\right)$. The end-point method was used to estimate creatinine concentration in urine via picrate and acidifier (commercial kits, Doles, Goiânia, Goiás, Brazil). The urinary volume was estimated for each animal by multiplying it by body weight (BW).

The $\mathrm{N}$ use efficiency compounds was obtained by the difference between the total ingested $\mathrm{N}$ and the total excreted $\mathrm{N}$ in the feces and the urine using the micro Kjeldahl method and according to the methodology described by the method 988.05 (AOAC, 1990).

Microbial protein synthesis was determined by the technique purine derivatives. The purine derivatives (i.e., allantoin, xanthine, hypoxanthine and uric acid) were determined according to Chen and Gomes (1992). The amount of absorbed microbial purine $\left(\mathrm{X} \mathrm{mmol} \mathrm{d}^{-1}\right)$ corresponding to the purine derivatives excreted $\left(\mathrm{Y} \mathrm{mmol} \mathrm{d}^{-1}\right)$ was calculated by the formula: $\mathrm{Y}=0.84 \mathrm{X}+\left(0.15 \mathrm{BW}^{0.75} \mathrm{e}^{-0.25} \mathrm{X}\right)$, where, $\mathrm{BW}$ is the body weight, and 0.84 the recovery of purines absorbed as purine derivatives in the urine. The microbial $\mathrm{N}$ supplied to the small intestine was calculated from the absorbed microbial purine $(\mathrm{X})$ using the formula: Microbial $\mathrm{N}\left(\mathrm{g} \mathrm{d}^{-1}\right)=(70 \mathrm{X}) /(0.83 \times 0.116 \times 1000)$, where, 70 represents the content of $\mathrm{N}$ in the purines $\left(\mathrm{mg} \mathrm{N} \mathrm{mmol}^{-1}\right)$, and 0.83 the digestibility of microbial purines.

\section{Performance evaluation}

To monitor performance, animals were weighed initially at the experimental period and at the end of each period after fasting of solid food for approximately $16 \mathrm{~h}$. In addition, animals were always weighed at the same time. After all three periods, animals were weighed to obtain final live weight (LWf) and average daily gain.

\section{Experimental design and statistical analysis}

The experiment was carried out as a randomized complete design, with four treatments (only Caatinga, Caatinga+Additive, Caatinga+Additive+Supplement and Caatinga+Supplement) and six animals for each treatment with each animal measured in three periods (rainy period, transition period and drought period). The statistical model used for analyses was $\mathrm{y}_{\mathrm{ijk}}=\mu+\tau_{\mathrm{i}}+\delta_{\mathrm{ij}}+\mathrm{t}_{\mathrm{k}}+(\tau * \mathrm{t})_{\mathrm{ik}}+\varepsilon_{\mathrm{ijk}}$, where: $\mathrm{y}_{\mathrm{ijk}}$ is observation $\mathrm{ijk}, \mu$ is the overall mean, $\tau_{\mathrm{i}}$ is the effect of treatment $\mathrm{i}$, $\mathrm{t}_{\mathrm{k}}$ is the effect of period $\mathrm{k},(\tau * \mathrm{t})_{\mathrm{ik}}$ is the effect of interaction between treatment $\mathrm{i}$ and period $\mathrm{k}, \delta_{\mathrm{ijj}}$ is random error with mean 0 and variance $\sigma^{2} \delta$, the variance between animals (subjects) within treatment and it is equal to the covariance between repeated measurements within animals and $\varepsilon_{\mathrm{ijk}}$ is random error with the mean 0 and variance $\sigma^{2}$, the variance between measurements within animals.

Data analysis was performed using the SAS version 9.1 (SAS Institute, Cary, North Carolina, USA). Data were analyzed using PROC MIXED to ANOVA. The CLASS statement defines categorical variables (treatment and period). The MODEL statement defines the dependent variable, and independent variables treatment, period and Treatment $\times$ Period interaction. The REPEATED statement defines the variance structure for repeated measurements (period). The subject $(\mathrm{SUB}=$ treatment) defines the variable on which repeated measurements were taken. The type of variancecovariance structure was compound symmetry $($ TYPE $=$ CS). The residuals normality (Shapiro-Wilk at $5 \%$ of probability) was analyzed by SAS UNIVARIATE (PROC UNIVARIATE). The standard error of mean (SEM) was analyzed through the original data. Differences among treatments were considered significant at $\mathrm{P}<0.05$. 


\section{RESULTS}

\section{Performance evaluation}

There was interaction $(\mathrm{P}<0.05)$ between treatments (phytogenic additive and supplementation) with periods (rainy, transition and drought periods) to performance evaluation (Table 4). The phytogenic additive from mesquite $(\mathrm{P}<0.05)$ exerted a significant effect on the initial (BWi) (except for the rainy period) and final body weight (LWf), total weight gain (TWG) and average daily gain (ADG) in the rainy and transition periods, where animals that received the additive had greater gains than those that did not receive it, and when they were not supplemented. In relation to supplementation, we observed that, among supplemented treatments, there was nonsignificant effect $(\mathrm{P}>0.05)$ of using the additive. In the drought period, results regarding sheep performance did not show any differences $(\mathrm{P}>0.05)$ between the analyzed treatments, obtaining low or negative TWG and ADG values.

\section{Nutrient intake}

There was interaction $(\mathrm{P}<0.05)$ between treatments with periods to nutrient intake (Table 5). The phytogenic additive had nonsignificant effects $(\mathrm{P}>0.05)$ on DM consumption, OM, NDF, CP and NFC. There was a significant difference $(\mathrm{P}<0.05)$ only for TDN consumption, obtaining a higher TDN consumption in the treatment that used the additive, when comparing treatments without supplementation. In the case of supplemented treatments, there were nonsignificant differences $(\mathrm{P}>$ 0.05 ) in nutrient consumption among treatments that did or did not use the additive. This result did not change only in the experimental drought period, where there were nonsignificant effects $(\mathrm{P}>0.05)$ on any variable and any treatment.

\section{Nutrient digestibility}

Nutrient digestibility was affected by interaction between treatments and periods $(\mathrm{P}<0.05)$ (Table 6). There was a significant difference in nutrient digestibility $(\mathrm{P}<0.05)$ between treatments without supplementation, with higher values for animals treated with the additive in the rainy and transition periods, except for NDF in the rainy period. The digestibility was not affected in treatments that received food supplementation, as well as in the drought period, and did not present significant differences $(\mathrm{P}>0.05)$.

\section{Nitrogen use efficiency and microbial protein synthesis}

The interaction between treatments and periods in $\mathrm{N}$ use efficiency and microbial protein synthesis was significant $(\mathrm{P}<0.05)$. The ingested $\mathrm{N}$ exerted nonsignificant effects $(\mathrm{P}>0.05)$ on either period or treatment. The $\mathrm{N}$ absorbed, retained, percentage of ingested $\mathrm{N}$ and percentage of $\mathrm{N}$ absorbed presented significant differences $(\mathrm{P}<0.05)$ between the rainy and transition periods treatments without feed supplementation, showing higher values when additive was used (Table 7).

Table 4. Performance of sheep receiving or not phytogenic additive from mesquite.

\begin{tabular}{|c|c|c|c|c|c|c|c|c|}
\hline \multirow[b]{2}{*}{ Parameters (kg) } & \multicolumn{4}{|c|}{ Treatments } & \multirow[b]{2}{*}{ SEM } & \multicolumn{3}{|c|}{$\mathrm{P}$ value } \\
\hline & Caatinga & $\begin{array}{c}\text { Caatinga+ } \\
\text { Additive }\end{array}$ & $\begin{array}{c}\text { Caatinga+Additive } \\
\text { +Supplement }\end{array}$ & $\begin{array}{c}\text { Caatinga+ } \\
\text { Supplement }\end{array}$ & & $\begin{array}{l}\text { Treatment } \\
(\mathrm{T})\end{array}$ & $\begin{array}{l}\text { Period } \\
(\mathrm{P})\end{array}$ & $\mathrm{T} * \mathrm{P}$ \\
\hline \multicolumn{9}{|c|}{ Rainy period } \\
\hline Initial body weight & 23.50 & 23.75 & 23.10 & 23.06 & 0.47 & $<0.001$ & $<0.001$ & $<0.001$ \\
\hline Final body weight & $31.48 \mathrm{c}$ & $34.25 b$ & $38.20 \mathrm{a}$ & $34.92 \mathrm{a}$ & 0.60 & $<0.001$ & $<0.001$ & $<0.001$ \\
\hline Total weight gain & $8.62 \mathrm{c}$ & $10.50 \mathrm{~b}$ & $13.75 \mathrm{a}$ & $11.90 \mathrm{a}$ & 0.50 & $<0.001$ & $<0.001$ & $<0.001$ \\
\hline Average daily gain & $0.17 \mathrm{c}$ & $0.22 b$ & $0.27 \mathrm{a}$ & $0.23 \mathrm{a}$ & 0.01 & $<0.001$ & $<0.001$ & $<0.001$ \\
\hline \multicolumn{9}{|c|}{ Transition period } \\
\hline Initial body weight & $31.48 \mathrm{c}$ & $34.25 \mathrm{~b}$ & $38.20 \mathrm{a}$ & $34.92 \mathrm{a}$ & 0.62 & $<0.001$ & $<0.001$ & $<0.001$ \\
\hline Final body weight & $35.42 \mathrm{c}$ & $38.54 b$ & $43.95 a$ & $39.84 \mathrm{a}$ & 0.75 & $<0.001$ & $<0.001$ & $<0.001$ \\
\hline Total weight gain & $3.94 \mathrm{c}$ & $4.66 \mathrm{~b}$ & $6.07 \mathrm{a}$ & $5.32 \mathrm{a}$ & 0.25 & $<0.001$ & $<0.001$ & $<0.001$ \\
\hline Average daily gain & $0.10 \mathrm{c}$ & $0.14 b$ & $0.18 \mathrm{a}$ & $0.15 \mathrm{a}$ & 0.01 & $<0.001$ & $<0.001$ & $<0.001$ \\
\hline \multicolumn{9}{|c|}{ Drought period } \\
\hline Initial body weight & $35.42 \mathrm{c}$ & $38.54 b$ & $43.95 \mathrm{a}$ & $39.84 \mathrm{a}$ & 0.75 & $<0.001$ & $<0.001$ & $<0.001$ \\
\hline Final body weight & $34.94 \mathrm{c}$ & $37.00 \mathrm{~b}$ & $45.50 \mathrm{a}$ & $40.04 \mathrm{a}$ & 1.02 & $<0.001$ & $<0.001$ & $<0.001$ \\
\hline Total weight gain & $-1.14 b$ & $-1.54 b$ & $2.28 \mathrm{a}$ & $1.17 \mathrm{a}$ & 0.40 & $<0.001$ & $<0.001$ & $<0.001$ \\
\hline Average daily gain & $-0.02 b$ & $-0.03 b$ & $0.04 \mathrm{a}$ & $0.02 \mathrm{a}$ & 0.00 & $<0.001$ & $<0.001$ & $<0.001$ \\
\hline
\end{tabular}

Means in rows followed by the same letters do not differ $(\mathrm{P}>0.05)$ by ANOVA considering repeated measures in time.

MSE: Standard error of the mean. 
The phytogenic additive $(\mathrm{P}<0.05)$ exerted a significant effect on microbial protein synthesis in rainy and transition periods, where animals that received additive had greater gains than those that did not receive it, and when they were not supplemented (Table 7).

In the drought period, there were nonsignificant effects on any variable ( $\mathrm{N}$ use efficiency and microbial protein synthesis) and on any treatment $(\mathrm{P}>0.05)$ (Table 7).

Table 5. Nutrient intake of sheep receiving or not phytogenic additive from mesquite.

\begin{tabular}{|c|c|c|c|c|c|c|c|c|}
\hline \multirow[b]{2}{*}{ Parameters $\left(\mathrm{g} \mathrm{d}^{-1}\right)$} & \multicolumn{4}{|c|}{ Treatments } & \multirow[b]{2}{*}{ SEM } & \multicolumn{3}{|c|}{$\mathrm{P}$ value } \\
\hline & Caatinga & $\begin{array}{c}\text { Caatinga+ } \\
\text { Additive }\end{array}$ & $\begin{array}{c}\text { Caatinga+Additive } \\
+ \text { Supplement }\end{array}$ & $\begin{array}{c}\text { Caatinga+ } \\
\text { Supplement }\end{array}$ & & $\begin{array}{l}\text { Treatment } \\
(\mathrm{T})\end{array}$ & $\begin{array}{l}\text { Period } \\
\text { (P) }\end{array}$ & $\mathrm{T} * \mathrm{P}$ \\
\hline \multicolumn{9}{|c|}{ Rainy period } \\
\hline Dry matter & $490.66 b$ & $502.64 b$ & $568.29 \mathrm{a}$ & $590.61 \mathrm{a}$ & 10.92 & $<0.001$ & $<0.001$ & $<0.001$ \\
\hline Organic matter & $419.85 b$ & $452.47 \mathrm{~b}$ & $529.54 \mathrm{a}$ & $520.60 \mathrm{a}$ & 10.69 & $<0.001$ & $<0.001$ & $<0.001$ \\
\hline Neutral detergent fiber & $282.37 \mathrm{a}$ & $289.27 \mathrm{a}$ & $295.51 \mathrm{a}$ & $306.94 a$ & 4.14 & 0.623 & $<0.001$ & $<0.001$ \\
\hline Crude protein & $81.02 \mathrm{~b}$ & $83.00 \mathrm{~b}$ & $100.24 \mathrm{a}$ & $104.22 \mathrm{a}$ & 2.37 & $<0.001$ & $<0.001$ & $<0.001$ \\
\hline Non-fibrous carbohydrates & $26.80 \mathrm{~b}$ & $27.46 b$ & $61.31 \mathrm{a}$ & $63.89 \mathrm{a}$ & 3.64 & $<0.001$ & $<0.001$ & $<0.001$ \\
\hline Total digestible nutrients & $199.52 \mathrm{c}$ & $244.51 b$ & $359.66 \mathrm{a}$ & $348.37 \mathrm{a}$ & 4.75 & $<0.001$ & $<0.001$ & $<0.001$ \\
\hline \multicolumn{9}{|c|}{ Transition period } \\
\hline Dry matter & $469.54 b$ & $506.40 \mathrm{~b}$ & $635.64 a$ & $663.52 \mathrm{a}$ & 18.43 & $<0.001$ & $<0.001$ & $<0.001$ \\
\hline Organic matter & $395.21 b$ & $446.82 b$ & $560.20 \mathrm{a}$ & $559.99 \mathrm{a}$ & 18.43 & $<0.001$ & $<0.001$ & $<0.001$ \\
\hline Neutral detergent fiber & $270.02 b$ & $291.22 b$ & $302.70 \mathrm{a}$ & $313.19 \mathrm{a}$ & 5.26 & $<0.001$ & $<0.001$ & $<0.001$ \\
\hline Crude protein & $66.42 b$ & $71.63 b$ & $101.23 \mathrm{a}$ & $106.17 \mathrm{a}$ & 3.73 & $<0.001$ & $<0.001$ & $<0.001$ \\
\hline Non-fibrous carbohydrates & $13.13 \mathrm{~b}$ & $14.17 b$ & $97.92 \mathrm{a}$ & $105.77 \mathrm{a}$ & 8.95 & $<0.001$ & $<0.001$ & $<0.001$ \\
\hline Total digestible nutrients & $164.49 \mathrm{c}$ & $204.67 b$ & $354.63 \mathrm{a}$ & $351.04 \mathrm{a}$ & 25.31 & $<0.001$ & $<0.001$ & $<0.001$ \\
\hline \multicolumn{9}{|c|}{ Drought period } \\
\hline Dry matter & $473.31 b$ & $444.28 b$ & $689.87 \mathrm{a}$ & $724.27 \mathrm{a}$ & 25.64 & $<0.001$ & $<0.001$ & $<0.001$ \\
\hline Organic matter & $425.91 b$ & $420.26 b$ & $649.09 \mathrm{a}$ & $661.69 \mathrm{a}$ & 24.53 & $<0.001$ & $<0.001$ & $<0.001$ \\
\hline Neutral detergent fiber & $311.77 \mathrm{~b}$ & $292.65 b$ & $347.71 \mathrm{a}$ & $371.35 \mathrm{a}$ & 6.89 & $<0.001$ & $<0.001$ & $<0.001$ \\
\hline Crude protein & $57.52 b$ & $54.00 \mathrm{~b}$ & $114.82 \mathrm{a}$ & $118.72 \mathrm{a}$ & 6.18 & $<0.001$ & $<0.001$ & $<0.001$ \\
\hline Non-fibrous carbohydrates & $6.65 b$ & $6.24 b$ & $88.35 \mathrm{a}$ & $88.11 \mathrm{a}$ & 8.23 & $<0.001$ & $<0.001$ & $<0.001$ \\
\hline Total digestible nutrients & $110.51 b$ & $114.15 b$ & $348.82 \mathrm{a}$ & $304.31 \mathrm{a}$ & 23.99 & $<0.001$ & $<0.001$ & $<0.001$ \\
\hline
\end{tabular}

Means in rows followed by the same letters do not differ $(\mathrm{P}>0.05)$ by ANOVA considering repeated measures in time.

SEM: Standard error of the mean.

Table 6. Nutrient digestibility by sheep that received or not the phytogenic additive from mesquite.

\begin{tabular}{|c|c|c|c|c|c|c|c|c|}
\hline \multirow[b]{2}{*}{ Parameters $\left(\mathrm{g} \mathrm{kg}^{-1}\right)$} & \multicolumn{4}{|c|}{ Treatments } & \multirow[b]{2}{*}{ SEM } & \multicolumn{3}{|c|}{$\mathrm{P}$ value } \\
\hline & Caatinga & $\begin{array}{l}\text { Caatinga+ } \\
\text { Additive }\end{array}$ & $\begin{array}{c}\text { Caatinga+Additive } \\
\text { +Supplement }\end{array}$ & $\begin{array}{l}\text { Caatinga+ } \\
\text { Supplement }\end{array}$ & & $\begin{array}{l}\text { Treatment } \\
(\mathrm{T})\end{array}$ & $\begin{array}{l}\text { Period } \\
(\mathrm{P})\end{array}$ & $\mathrm{T} * \mathrm{P}$ \\
\hline \multicolumn{9}{|c|}{ Rainy period } \\
\hline Dry matter & $391.64 \mathrm{c}$ & $437.25 b$ & $521.82 \mathrm{a}$ & $502.79 a$ & 13.50 & $<0.001$ & $<0.001$ & $<0.001$ \\
\hline Organic matter & $441.09 \mathrm{c}$ & $492.41 b$ & $571.89 \mathrm{a}$ & $549.60 \mathrm{a}$ & 13.60 & $<0.001$ & $<0.001$ & $<0.001$ \\
\hline Neutral detergent fiber & $419.39 b$ & $448.80 \mathrm{~b}$ & $480.32 \mathrm{a}$ & $463.41 \mathrm{a}$ & 9.77 & $<0.001$ & $<0.001$ & $<0.001$ \\
\hline Crude protein & $367.71 \mathrm{c}$ & $421.39 \mathrm{~b}$ & $512.77 \mathrm{a}$ & $544.37 \mathrm{a}$ & 19.88 & $<0.001$ & $<0.001$ & $<0.001$ \\
\hline Total digestible nutrients & $406.03 \mathrm{c}$ & $464.51 b$ & $597.07 \mathrm{a}$ & $571.35 \mathrm{a}$ & 19.29 & $<0.001$ & $<0.001$ & $<0.001$ \\
\hline \multicolumn{9}{|c|}{ Transition period } \\
\hline Dry matter & $367.42 \mathrm{c}$ & $435.43 b$ & $541.33 \mathrm{a}$ & $550.58 \mathrm{a}$ & 20.10 & $<0.001$ & $<0.001$ & $<0.001$ \\
\hline Organic matter & $433.25 \mathrm{c}$ & $578.87 \mathrm{~b}$ & $590.98 \mathrm{a}$ & $604.07 \mathrm{a}$ & 23.96 & $<0.001$ & $<0.001$ & $<0.001$ \\
\hline Neutral detergent fiber & $367.94 \mathrm{c}$ & $433.36 b$ & $444.47 \mathrm{a}$ & $441.44 \mathrm{a}$ & 13.11 & $<0.001$ & $<0.001$ & $<0.001$ \\
\hline Crude protein & $514.71 \mathrm{c}$ & $559.94 b$ & $607.04 \mathrm{a}$ & $627.14 \mathrm{a}$ & 13.34 & $<0.001$ & $<0.001$ & $<0.001$ \\
\hline Total digestible nutrients & $415.87 \mathrm{c}$ & $553.80 \mathrm{~b}$ & $634.56 \mathrm{a}$ & $629.66 \mathrm{a}$ & 26.36 & $<0.001$ & $<0.001$ & $<0.001$ \\
\hline \multicolumn{9}{|c|}{ Drought period } \\
\hline Dry matter & $402.64 b$ & $426.03 b$ & $612.23 \mathrm{a}$ & $600.29 \mathrm{a}$ & 24.17 & $<0.001$ & $<0.001$ & $<0.001$ \\
\hline Organic matter & $445.26 b$ & $469.83 b$ & $638.37 \mathrm{a}$ & $625.78 \mathrm{a}$ & 22.15 & $<0.001$ & $<0.001$ & $<0.001$ \\
\hline Neutral detergent fiber & $358.58 b$ & $400.12 b$ & $538.11 \mathrm{a}$ & $511.50 \mathrm{a}$ & 20.81 & $<0.001$ & $<0.001$ & $<0.001$ \\
\hline Crude protein & $458.82 b$ & $501.05 b$ & $696.42 \mathrm{a}$ & $666.53 \mathrm{a}$ & 25.97 & $<0.001$ & $<0.001$ & $<0.001$ \\
\hline Total digestible nutrients & $447.86 b$ & $477.80 \mathrm{~b}$ & $563.89 \mathrm{a}$ & $530.00 \mathrm{a}$ & 12.68 & $<0.001$ & $<0.001$ & $<0.001$ \\
\hline
\end{tabular}

Means in rows followed by the same letters do not differ $(\mathrm{P}>0.05)$ by ANOVA considering repeated measures in time.

SEM: Standard error of the mean. 
Table 7. Nitrogen use efficiency and microbial protein synthesis of sheep grazing in the semiarid.

\begin{tabular}{|c|c|c|c|c|c|c|c|c|}
\hline \multirow[b]{2}{*}{ Parameters } & \multicolumn{4}{|c|}{ Treatments } & \multirow[b]{2}{*}{ SEM } & \multicolumn{3}{|c|}{$P$ value } \\
\hline & Caatinga & $\begin{array}{l}\text { Caatinga+ } \\
\text { Additive }\end{array}$ & $\begin{array}{l}\text { Caatinga+Additive } \\
\text { +Supplement }\end{array}$ & $\begin{array}{c}\text { Caatinga+ } \\
\text { Supplement }\end{array}$ & & $\begin{array}{l}\text { Treatment } \\
\text { (T) }\end{array}$ & $\begin{array}{l}\text { Period } \\
\text { (P) }\end{array}$ & $\mathrm{T} * \mathrm{P}$ \\
\hline \multicolumn{9}{|c|}{ Rainy season } \\
\hline Ingested $\mathrm{N}, \mathrm{g} \mathrm{d}^{-1}$ & $11.32 b$ & $12.03 b$ & $15.02 \mathrm{a}$ & $15.24 \mathrm{a}$ & 0.43 & $<0.001$ & $<0.001$ & $<0.001$ \\
\hline Absorbed $\mathrm{N}, \mathrm{g} \mathrm{d}^{-1}$ & $3.06 \mathrm{c}$ & $4.37 \mathrm{~b}$ & $6.99 \mathrm{a}$ & $7.75 \mathrm{a}$ & 0.47 & $<0.001$ & $<0.001$ & $<0.001$ \\
\hline Retained $\mathrm{N}, \mathrm{g} \mathrm{d}^{-1}$ & $2.23 \mathrm{c}$ & $3.07 \mathrm{~b}$ & $5.95 \mathrm{a}$ & $6.27 \mathrm{a}$ & 0.45 & $<0.001$ & $<0.001$ & $<0.001$ \\
\hline Retained N:ingested N, $\mathrm{g} \mathrm{kg}^{-1}$ & $198.46 \mathrm{c}$ & $252.30 \mathrm{~b}$ & $395.02 \mathrm{a}$ & $419.85 a$ & 25.20 & $<0.001$ & $<0.001$ & $<0.001$ \\
\hline Retained N:absorbed N, $\mathrm{g} \mathrm{kg}^{-1}$ & $726.06 \mathrm{c}$ & $765.75 b$ & $853.62 \mathrm{a}$ & $854.20 \mathrm{a}$ & 17.85 & $<0.001$ & $<0.001$ & $<0.001$ \\
\hline Microbial protein synthesis, $\mathrm{g} \mathrm{d}^{-1}$ & $26.09 \mathrm{c}$ & $46.15 b$ & $69.83 a$ & $48.45 b$ & 3.08 & $<0.001$ & $<0.001$ & $<0.001$ \\
\hline \multicolumn{9}{|c|}{ Transition period } \\
\hline Ingested $\mathrm{N}, \mathrm{g} \mathrm{d}^{-1}$ & $11.84 b$ & $12.69 \mathrm{~b}$ & $17.94 \mathrm{a}$ & $18.62 \mathrm{a}$ & 0.64 & $<0.001$ & $<0.001$ & $<0.001$ \\
\hline Absorbed $\mathrm{N}, \mathrm{g} \mathrm{d}^{-1}$ & $5.76 \mathrm{c}$ & $7.10 \mathrm{~b}$ & $11.08 \mathrm{a}$ & $11.94 \mathrm{a}$ & 0.57 & $<0.001$ & $<0.001$ & $<0.001$ \\
\hline Retained $\mathrm{N}, \mathrm{g} \mathrm{d}^{-1}$ & $4.59 \mathrm{c}$ & $5.93 b$ & $9.62 \mathrm{a}$ & $10.62 \mathrm{a}$ & 0.55 & $<0.001$ & $<0.001$ & $<0.001$ \\
\hline Retained $\mathrm{N}$ :ingested $\mathrm{N}, \mathrm{g} \mathrm{kg}^{-1}$ & $385.44 \mathrm{c}$ & $467.20 \mathrm{~b}$ & $534.73 \mathrm{a}$ & $568.85 \mathrm{a}$ & 19.52 & $<0.001$ & $<0.001$ & $<0.001$ \\
\hline Retained $\mathrm{N}$ :absorbed $\mathrm{N}, \mathrm{g} \mathrm{kg}^{-1}$ & $791.10 \mathrm{c}$ & $833.21 b$ & $866.98 \mathrm{a}$ & $888.96 \mathrm{a}$ & 10.55 & $<0.001$ & $<0.001$ & $<0.001$ \\
\hline Microbial protein synthesis, $\mathrm{g} \mathrm{d}^{-1}$ & $24.81 \mathrm{c}$ & $44.14 b$ & $53.80 \mathrm{a}$ & $35.91 b$ & 2.59 & $<0.001$ & $<0.001$ & $<0.001$ \\
\hline \multicolumn{9}{|c|}{ Drought period } \\
\hline Ingested $\mathrm{N}, \mathrm{g} \mathrm{d}^{-1}$ & $10.68 \mathrm{~b}$ & $10.17 b$ & $18.67 \mathrm{a}$ & $18.99 \mathrm{a}$ & 0.90 & $<0.001$ & $<0.001$ & $<0.001$ \\
\hline Absorbed $\mathrm{N}, \mathrm{g} \mathrm{d}^{-1}$ & $4.97 b$ & $4.80 \mathrm{~b}$ & $12.38 \mathrm{a}$ & $12.25 \mathrm{a}$ & 0.81 & $<0.001$ & $<0.001$ & $<0.001$ \\
\hline Retained $\mathrm{N}, \mathrm{g} \mathrm{d}^{-1}$ & $4.58 \mathrm{~b}$ & $4.43 b$ & $11.97 \mathrm{a}$ & $11.84 \mathrm{a}$ & 0.80 & $<0.001$ & $<0.001$ & $<0.001$ \\
\hline Retained $\mathrm{N}$ :ingested $\mathrm{N}, \mathrm{g} \mathrm{kg}^{-1}$ & $428.31 b$ & $434.60 b$ & $638.53 \mathrm{a}$ & $623.12 \mathrm{a}$ & 22.74 & $<0.001$ & $<0.001$ & $<0.001$ \\
\hline Retained N:absorbed $\mathrm{N}, \mathrm{g} \mathrm{kg}^{-1}$ & $920.76 b$ & $923.85 b$ & $966.11 \mathrm{a}$ & $966.62 \mathrm{a}$ & 9.16 & $<0.001$ & $<0.001$ & $<0.001$ \\
\hline Microbial protein synthesis, $\mathrm{g} \mathrm{d}^{-1}$ & $25.90 \mathrm{a}$ & $26.89 \mathrm{a}$ & $21.97 \mathrm{a}$ & $22.58 \mathrm{a}$ & 2.60 & $<0.001$ & $<0.001$ & $<0.001$ \\
\hline
\end{tabular}

Means in rows followed by the same letters do not differ $(\mathrm{P}>0.05)$ by ANOVA considering repeated measures in time.

SEM: Standard error of the mean.

\section{DISCUSSION}

In this study, we observed that the use of secondary compounds did not cause any positive or negative effects on DM, $\mathrm{OM}, \mathrm{NDF}, \mathrm{CP}$ and NFC consumption, actually promoting a TDN consumption improvement. This result is considered satisfactory, since the presence of secondary plants metabolites may affect food acceptability (Bonfim et al., 2012). Zhou et al. (2012), Geraci et al. (2012) and Silva et al. (2016) evaluated the use of secondary compounds in small ruminant' feeding and they also found nonsignificant effects on nutrient intake. However, according to Ali et al. (2012), the use of secondary compounds in ruminant animal diets was valuable as an alternative to improve animal feed intake.

The use of the mesquite extract as a phytogenic additive increased weight gain, reflected on final body weight, total weight gain and average daily gain. The performances were better in the treatment that used additive without supplementation (Table 4). It was likely that the tannins within the additive caused changes in the ruminal microbiota with a consequent increase in microbial proteins and better digestibility of nutrients (Tables 6 and 7). Likewise, it occurred with data reported by Ali et al. (2012), who observed an improvement in the performance of animals when using secondary compounds. There was a greater efficiency in the use of $\mathrm{N}$, and consequently better muscle mass gain, leading to weight gain in animals that used the phytogenic additive without supplementation, corroborated with data of weight gain provided here (Table 7). The positive $\mathrm{N}$ balance indicated that animals were under $\mathrm{N}$ gain conditions (Santos et al., 2015; Mizubuti et al., 2016; Moraes et al., 2016).

The tannins found in the mesquite pod extract (Table 2) increased the synthesis of microbial protein (Table 7). Thus, phytogenic additive favored protein and energy synchrony, providing a better ruminal microbiota performance and consequently increased flow to the small intestine. Jayanegara et al. (2015) observed that addition of tannins increased the microbial supply. Therefore, the flow of microbial protein in the small intestine increases due to the amount and the fact that tannins form complexes with proteins, increasing the digestibility of $\mathrm{CP}$ and also the digestibility of DM, OM and TDN, as occurred here (Table 6). This digestibility is responsible for the best performance observed. Similar results of a digestibility improvement were reported by Silva et al. (2016) and Alves Júnior et al. (2017). 
All effects on performance and digestibility by using mesquite pod extract can be analyzed. Data on consumption of nutrients can be associated with them (Table 5). There was an increase in total and daily weight gain associated to the fact that it did not change DM consumption and promoted an increase in TDN consumption, a reflection of the improvement in digestibility. Thus, the additive promoted a high consumption of TDN, which is reflected in a high energy available to the animal and a greater nutritional intake.

This can be explained by the improvement of digestibility which, in turn, occurs due to secondary compounds and their direct action on the ruminal fermentation process, since there is a decrease in protozoa together with an increase in gramnegative bacteria. The degradation of food in the rumen is more efficient since the number of bacteria increases (Bodas et al., 2012; Alves Júnior et al., 2017). In an experiment conducted by Ghasemi et al. (2012), the inclusion of tannins in diets was associated with the reduction in cellulolytic bacteria, which are gram-positive, because they undergo an inhibitory effect and consequently a decrease in proteolysis. Hutton et al. (2012) and Alves Júnior et al. (2017) also reported such a decrease in gram-positive bacteria. Gram-positive bacteria in the rumen have low molecular weight, so they are prone to the action of tannins, and are consequently inhibited (Benchaar and Greathead, 2011; Patra and Saxena, 2011; Francisco et al., 2015; Morales and Ungerfeld, 2015; Thao et al., 2015). Pulido et al. (2020) reported that the addition of lactic acid bacteria as additive increased the metabolizable energy content of the silage and reduced its butyrate concentration.

The difference between rainy and transition periods in relation to the best performance is related not only to animal growth, but also to the characteristic of the Caatinga itself, which was shown to be of lower quality during the experimental period. This can be evidenced by analyzing the protein content in the composition of the extrusa (Table 3 ) and the forage mass (Table 1) during the period mentioned. At the end of the experimental period, the same effect was not observed for any of the variables, noting that there was in fact a food deficiency, since Caatinga was already in a poor condition with a low food supply (Table 1). In this case, the additive became irrelevant.

At the end of the third experimental period, consumption, digestibility and performance resulted in no effects arising from the additive, exerting only the effects from feed supplement provided. As regards the treatments that received food supplementation, the additive had no such effects since supplement was sufficient to generate the growth of gramnegative bacteria with a consequent non-influence of the extract used.

Nitrogen retention and microbial protein synthesis (Table 7) were better in the treatment that used the additive without supplementation, showing its greater use by animals and suggesting a ruminal degradation protein supply with less amount of excreted $\mathrm{N}$, possibly captured during ruminal metabolism. The ratio retained $\mathrm{N}$ :ingested $\mathrm{N}$ was higher in non-supplemented animals using the additive, showing that $27.12 \%$ rainy period and $21.21 \%$ transition period of $\mathrm{N}$ were retained in the animal (Table 7). At the drought period, the same effect was not observed in $\mathrm{N}$ balance, since Caatinga was already in a poor condition with a low food supply (Table 1) and bromatological composition (Table 3). The same improvement occurred with the ratio retained $\mathrm{N}$ :absorbed $\mathrm{N}$. In relation to the nonsignificant effect on the supplemented treatments, Moreno et al. (2010) explained that high concentrate levels reflect in a high $\mathrm{N}$ uptake and retention, and that $\mathrm{N}$ balance is influenced by concentrate content.

\section{CONCLUSIONS}

The use of mesquite extract as a phytogenic additive is recommended for animals finished in the pasture in the semiarid when they have plenty of quality pasture available and are not supplemented. However, for supplemented animals, there are no such satisfactory effects. It also provides no satisfactory results when non-supplemented animals are supplemented with a poor-quality pasture and a low availability.

\section{ACKNOWLEDGEMENTS}

The authors would like to thank the Foundation for Science and Technology Support from Pernambuco for project financing, project number: APQ-1689-5.04/12. 


\section{REFERENCES}

Abdelmohsen, U.R., Grkovic, T., Balasubramanian, S., Kamel, M.S., Quinn, R.J., and Hentschel, U. 2015. Elicitation of secondary metabolism in actinomycetes. Biotechnology Advances 33:798-811. doi.org/10.1016/j.biotechadv.2015.06.003.

Agrawal, A.A., and Weber, M.G. 2015. On the study of plant defence and herbivory using comparative approaches: how important are secondary plant compounds. Ecology Letters 18:985-991. doi:10.1111/ele.12482.

Ali, A.S., Tudsri, S., Rungmekarat, S., and Kaewtrakulpong, K. 2012. Effect of feeding Prosopis juliflora pods and leaves on performance and carcass characteristics of afar sheep. Kasetsart Journal Natural Science 46:871-881.

Alves Júnior, R.T., Souza, E.J.O., Melo, A.A.S., Silva, K.A.S., Torres, T.S., Pereira, G.F.C., et al. 2017. Mesquite extract as phytogenic additive to improve the nutrition of sheep. Journal of Agricultural Science 9:1916-9752. doi.org/10.5539/jas.v9n7p164.

Andrade-Montemayor, H.M., Cordova-Torees, A.V., García-Gasca, T., and Kawas, J.R. 2011. Alternative foods for small ruminants in semiarid zones, the case of Mesquite (Prosopis laevigata spp.) and Nopal (Opuntia spp.) Small Ruminant Research 98:83-92. doi.org/10.1016/j.smallrumres.2011.03.023.

AOAC. 1990. Official methods of analysis of AOAC. $15^{\text {th }}$ ed. Association of Official Analytical Chemists (AOAC) International, Arlington, Virginia, USA.

Benchaar, C., and Greathead, H. 2011. Essential oils and opportunities to mitigate enteric methane emissions from ruminants. Animal Feed Science and Technology 166:338-355. doi.10.1016/j.anifeedsci.2011.04.024.

Bodas, R., Prieto, N., González, R.G., Andrés, S., Giráldez, F.J., and López, S. 2012. Manipulation of rumen fermentation and methane production with plant secondary metabolites. Animal Feed Science and Technology 176:78-93. doi.org/10.1016/j.anifeedsci.2012.07.01.

Bonfim, M.A.D., Barcelos, D.G., Facó, O., Oliveira, L.S., Gonsalves, J.L., Oliveira, K.S., et al. 2012. Consumo e produção de leite de cabras alimentadas com pedúnculo de caju e níveis crescentes de óleo de soja. Revista Científica de Produção Animal 14:85-88. doi.org/10.15528/2176-4158/ rcpa.v14n1p85-88.

Cabral Filho, S.L.S., Abdalla, A.L., Bueno, I.C.S., Gobbo, S.P., and Oliveira, A.A.A. 2013. Effect of sorghum tannins in sheep feed with high-concentrate diets. Brazilian Journal of Veterinary and Animal Science 65:1759-1766. doi.org/10.1590/S0102-09352013000600025.

Casali, A.O., Detmann, E., Valadares Filho, S.C., Pereira, J.C., Henriques, L.T., Freitas, S.G., et al. 2008. Influence of incubation time and particles size on indigestible compounds contents in cattle feeds and feces obtained by in situ procedures. Brazilian Journal of Animal Science 37:335-342.

Castro-Montoya, J.M., Makkar, H.P.S., and Becker, K. 2011. Chemical composition of rumen microbial fraction and fermentation parameters as affected by tannins and saponins using an in vitro rumen fermentation system. Canadian Journal of Animal Science 91:433-448. doi.org/10.1139/CJAS 2010-028.

Catalan, A.A.S., Gopinger, E., Lopes, D.C.N., Gonçalves, F.M., Roll, A.A.P., Xavier, E.G., et al. 2012. Phytogenic additives in animal nutrition: Panax ginseng. Revista Portuguesa de Ciências Veterinárias 107:15-21.

Chaves, T.P., Santana, C.P., Veras, G., Brandão, D.O., Felismino, D.C., Medeiros, A.C.D., et al. 2013. Seasonal variation in the production of secondary metabolites and antimicrobial activity of two plant species used in Brazilian traditional medicine. African Journal of Biotechnology 12:847-853.

Chen, X.B., and Gomes, M.J. 1992. Estimation of microbial protein supply to sheep and cattle based on urinary excretion of purine derivatives. An overview of technical details. International Feed Resource Unit. Occasional Publication. Rowet Research Institute, Bucksburn, Aberdeen, UK.

Durmic, Z., and Blache, D. 2012. Bioactive plants and plant products: Effects on animal function, health and welfare. Animal Feed Science and Technology 176:150-162. doi.org/10.1016/j.anifeedsci.2012.07.018.

Flachowsky, G., and Lebzien, P. 2012. Effects of phytogenic substances on rumen fermentation and methane emissions: A proposal for a research process. Animal Feed Science and Technology 176:70-77. doi.org/10.1016/j.anifeedsci.2012.07.009.

Francisco, A., Dentinho, M.T., Alves, S.P., Portugal, P.V., Fernandes, F., Sengo, S., et al. 2015. Growth performance, carcass and meat quality of lambs supplemented with increasing levels of a tanniferous bush (Cistus ladanifer L.) and vegetable oils. Meat Science 100:275-282. doi.org/10.1016/j.meatsci.2014.10.014.

Geraci, J.I., Garciarena, A.D., Gagliostro, G.A., Beauchemin, K.A., and Colombatto, D. 2012. Plants extracts containing cinnamaldehyde, eugenol and capsicum oleoresin added to feedlot cattle diets: Ruminal environment, short term intake patterns and animal performance. Animal Feed Science and Technology 176:23-130. doi.10.1016/j.anifeedsci.2012.07.015.

Ghasemi, S., Naserian, A.A., Valizadeh, V., Tahmasebi, A.M., Vakili, A.R., Behgar, M., et al. 2012. Inclusion of pistachio hulls as a replacement for alfalfa hay in the diet of sheep causes a shift in the rumen cellulolytic bacterial population. Small Ruminant Research 104:94-98.

Hall, M.B. 2000. Calculation of non-structural carbohydrate content of feeds that contain non-protein nitrogen. Bulletin 339. p. 25-34. University of Florida, Gainesville, Florida, USA. 
Hutton, P.G., Durmic, Z., Ghisalberti, E.L., Flematti, G.R., Duncan, R.M., Carson, C.F., et al. 2012. Inhibition of ruminal bacteria involved in lactic acid metabolism by extracts from Australian plants. Animal Feed Science and Technology 176:170-177. doi.org/10.1016/j.anifeedsci.2012.07.020.

IPA. 2015. Instituto Agronômico de Pernambuco. Sessão de índices pluviométricos, Recife, Brasil. Available at http://www.ipa.br/indice_pluv.php\#calendario_indices (accessed June 2017).

Jayanegara, A., Goel, G., Makkar, H.P.S., and Becker, K. 2015. Divergence between purified hydrolysable and condensed tannin effects on methane emission, rumen fermentation and microbial population in vitro. Animal Feed Science and Technology 209:60-68. doi.org/10.1016/j.anifeedsci.2015.08.002.

Marques, T.V., Mendes, K., Mutti, P., Medeiros, S., Silva, L., Perez-Marin, A.M., et al. 2020. Environmental and biophysical controls of evapotranspiration from Seasonally Dry Tropical Forests (Caatinga) in the Brazilian Semiarid. Agricultural and Forest Meteorology 287:107957. doi.org/10.1016/j. agrformet.2020.107957.

Mizubuti, I.Y., Syperreck, M.A., Ribeiro, E.L.A., Pereira, E.S., Pinto, A.P., Prado, O.P.P., et al. 2016. Intake, digestibility and nitrogen balance in sheep fed with diets containing Crambe cake. Brazilian Journal of Veterinary and Animal Science 68:761-768. doi.10.1590/1678-4162-8618.

Moraes, G.S.O., Souza, E.J.O., Véras, A.S.C., Almeida, M.P., Cunha, M.V., Torres, T.R., et al. 2016. Total replacement of corn by mesquite pod meal considering nutritional value, performance, feeding behavior, nitrogen balance, and microbial protein synthesis of Holstein-Zebu crossbred dairy steers. Tropical Animal Health Production 48:1415-1420. doi.org/10.1007/s11250-016-1108-4.

Morales, R., and Ungerfeld, E.M. 2015. Use of tannins to improve fatty acids profile of meat and milk quality in ruminants: A review. Chilean Journal of Agricultural Research 75:239-248. doi:10.4067/S0718-58392015000200014.

Moreno, G.M.B., Sobrinho, A.G.S., Leão, A.G., Loureiro, C.M.B., Perez, H.L., and Rossi, R.C. 2010. Performance, digestibility and nitrogen balance of lambs fed corn silage or sugar cane based diets with two levels of concentrate. Brazilian Journal of Animal Science 39:853-860. doi.org/10.1590/S1516-35982010000400022.

NRC. 2007. Nutrient requirements of small ruminants: Sheep, goats, cervids, and New World camelids. National Research Council (NRC), National Academy of Science, Washington, D.C., USA.

Oskoueian, E., Abdullah, N., and Oskoueian, A. 2013. Effects of flavonoids on rumen fermentation activity, methane production, and microbial population. BioMed Research International 2013:ID349129. doi:10.1155/2013/349129.

Patra, A.K., and Saxena, J. 2011. Exploitation of dietary tannins to improve rumen metabolism and ruminant nutrition. Journal of the Science of Food and Agriculture 91:24-37. doi.org/10.1002/jsfa.4152.

Pavarini, D.P., Pavarini, S.P., Niehues, M., and Lopes, N.P. 2012. Exogenous influences on plant secondary metabolite levels. Animal Feed Science and Technology 176:5-16. doi.org/10.1016/j.anifeedsci.2012.07.002.

Possamai, A.P.S., Lala, B., Pereira, V.V., Gomes, L.C., and Silva, S.C.C. 2011. Rumen modifiers: a review. Brazilian Journal of Biosystems Engineering 5:108-116. doi.org/10.18011/bioeng2011v5n2108-116.

Pulido, R., García, E., Beltrán, I., Daza, J., Keim, J., and Castillo, I. 2020. Effect of a homofermentative lactic acid bacteria additive on the quality of sugar-beet pulp silage and animal response of dairy cows with restricted access to pasture. Chilean Journal of Agricultural Research 80:234-240. doi:10.4067/S0718-58392020000200234.

Saliba, E.O.S., Silva, F.A.E., Silva, C.R.M.E., Rodríguez, N.M., Barbosa, G.S.S.C., Borges, A.L.C.C., et al. 2014. Utilization of markers LIPE and TiO2 compared to total collection of feces on determination of digestibility and fecal output in bovines. Animal Production Science 30:125.

Santos, G.R.A., Batista, A.M.V., Guim, A., Santos, M.V.F., Silva, M.J.A., and Pereira, V.L.A. 2008. Evaluation of botanical composition of sheep diet in Caatinga pasture. Revista Brasileira de Zootecnia 37:1876-1883. doi.org/10.1590/S1516-35982008001000023.

Santos, E.J., Pereira, M.L.A., Almeida, P.J.P., Moreira, J.V., Souza, A.C.S., Pereira, C.A.R., et al. 2015. Mesquite pod meal in diets for Santa Inês sheep: ingestive behavior. Acta Scientiarum. Animal Science 35:55-59. doi.10.4025/actascianimsci.v35i2.16221.

Silva, N.V., Costa, R.G., Freitas, C.R.G., Galindo, M.C.T., and Silva, L.S. 2010. Sheep feeding in semi-arid regions of Brazil. Acta Veterinaria Brasilica 4:233-241. doi.org/10.21708/avb.2010.4.4.1906.

Silva, C.S., Souza, E.J.O., Pereira, G.F.C., Cavalcante, E.O., Lima, E.I.M., Torres, T.R., et al. 2016. Plant extracts as phytogenic additives considering intake, digestibility, and feeding behavior of sheep. Tropical Animal Health and Production 49:353359. doi:10.1007/s11250-016-1199-y.

Sniffen, C.J., O'Connor, J.D., Van Soest, P.J., Fox, D.G., and Russell, J.B. 1992. A net carbohydrate and protein system for evaluating cattle diets: II. Carbohydrate and protein availability. Journal of Animal Science 70:35623577. doi.org/10.2527/1992.70113562x.

Terrill, T.H., Rowan, A.M., Douglas, G.B., and Barry, T.N. 1992. Determination of extractable and bound condensed tannin concentrations in forage plants, protein concentrate meals and cereal grains. Journal of the Science of Food and Agriculture 583:321-329. doi.org/10.1002/jsfa. 2740580306. 
Thao, N.T., Wanapat, M., Kang, S., and Cherdthong, A. 2015. Effects of supplementation of eucalyptus (E. camaldulensis) leaf meal on feed intake and rumen fermentation efficiency in swamp buffaloes. Asian-Australasian Journal of Animal Sciences 28: 951-957. doi. org/10.5713/ajas.14.0878.

Van Soest, P.J., Robertson, J.B., and Lewis, B.A. 1991. Methods for dietary fiber, neutral detergent fiber, and nonstarch polysaccharides in relation to animal nutrition. Journal of Dairy Science 74:3583-3597. doi.org/10.3168/jds.S0022-0302(91)78551-2.

Weiss, W.P. 1999. Energy prediction equations for ruminant feeds. p. 176-185. In Cornell Nutrition Conference for Feed Manufacturers, Ithaca. Cornell University, Ithaca, New York, USA.

Zhou, C.S., Xiao, W.J., Tan, Z.L., Salem, A.Z.M., Geng, M.M., Tang, S.X., et al. 2012. Effects of dietary supplementation of tea saponins (Ilex kudingcha C.J. Tseng) on ruminal fermentation, digestibility and plasma antioxidant parameters in goats. Animal Feed Science and Technology 176:163-169. doi.10.1016/j.anifeedsci.2012.07.019. 